\title{
CdTe Nanocrystal Hetero-Junction Solar Cells with High Open Circuit Voltage Based on Sb-doped $\mathrm{TiO}_{2}$ Electron Acceptor Materials
}

\author{
Miaozi Li ${ }^{1}$, Xinyan Liu ${ }^{1}$, Shiya Wen ${ }^{1}$, Songwei Liu ${ }^{1}$, Jingxuan Heng ${ }^{1}$, Donghuan Qin ${ }^{2, *}$, \\ Lintao Hou $^{3, *}$, Hongbin $\mathrm{Wu}^{2}$, Wei $\mathrm{Xu}^{2}$ and Wenbo Huang ${ }^{2}$ \\ 1 School of Materials Science and Engineering, South China University of Technology, Guangzhou 510640, \\ China; limz4994@sina.com (M.L.); liuxy0310@sina.com (X.L.); a740176840@163.com (S.W.); \\ majestyv@sina.com (S.L.); hengjingxuan@163.com (J.H.) \\ 2 Institute of Polymer Optoelectronic Materials \& Devices, State Key Laboratory of Luminescent Materials \& \\ Devices, South China University of Technology, Guangzhou 510640, China; hbwu@scut.ed.cn (H.W.); \\ xuwei@scut.ed.cn (W.X.); pswbh@scut.ed.cn (W.H.) \\ 3 Siyuan Laboratory, Guangzhou Key Laboratory of Vacuum Coating Technologies and New Energy \\ Materials, Department of Physics, Jinan University, Guangzhou 510632, China \\ * $\quad$ Correspondence: qindh@scut.edu.cn (D.Q.); thlt@jnu.edu.cn (L.H.); Tel.: +86-20-8711-4346 (D.Q.) \\ Academic Editor: Hao-chung Kuo \\ Received: 13 April 2017; Accepted: 28 April 2017; Published: 3 May 2017
}

\begin{abstract}
We propose Sb-doped $\mathrm{TiO}_{2}$ as electron acceptor material for depleted CdTe nanocrystal (NC) hetero-junction solar cells. Novel devices with the architecture of FTO/ZnO/Sb:TiO $2 / \mathrm{CdTe} / \mathrm{Au}$ based on $\mathrm{CdTe} \mathrm{NC}$ and $\mathrm{TiO}_{2}$ precursor are fabricated by rational ambient solution process. By introducing $\mathrm{TiO}_{2}$ with dopant concentration, we are able to tailor the optoelectronic properties of NC solar cells. Our novel devices demonstrate a very high open circuit voltage of $0.74 \mathrm{~V}$, which is the highest $V_{\mathrm{oc}}$ reported for any CdTe NC based solar cells. The power conversion efficiency (PCE) of solar cells increases with the increase of Sb-doped content from $1 \%$ to $3 \%$, then decreases almost linearly with further increase of $\mathrm{Sb}$ content due to the recombination effect. The champion device shows $J_{\mathrm{sc}}, V_{\mathrm{oc}}$, $\mathrm{FF}$, and PCE of $14.65 \mathrm{~mA} / \mathrm{cm}^{2}, 0.70 \mathrm{~V}, 34.44$, and $3.53 \%$ respectively, which is prospective for solution processed NC solar cells with high $V_{\mathrm{oc}}$.
\end{abstract}

Keywords: nanocrystal; solar cells; CdTe; heterojunction

\section{Introduction}

Nanocrystal (NC) solar cells have received extensive attention in the last several years due to their many advantages-such as low cost, environmental friendliness, solution process, simple device technics, and compatible roll-to-roll manufacturing [1-8]. The most efficient NC based solar cells nowadays are fabricated by using CdTe or PbS NC as donors with wide bandgap semiconductor materials as acceptors [9-13]. Compared to PbS NC, CdTe NC is less complex and more stable in air, which permits devices to be fabricated under ambient conditions. Thus, CdTe NC thin film has been studied intensively [14-20]. The working principle of efficient CdTe NC solar cells is based on the $\mathrm{p}-\mathrm{n}$ heterojunction that contains two media: an electron donor and electron acceptor. To prepare a high quality CdTe NC donor absorber, a layer by layer sintering process should be carried out to eliminate stress and defects in CdTe NC thin film [21,22]. The electron acceptor materials-typically $\mathrm{ZnO}, \mathrm{CdSe}$ or other n-type semiconductor thin films-are thus the key to improve the device performance. The most efficient CdTe NC-ZnO solar cells are fabricated by using a normal structure of ITO/CdTe/ $\mathrm{ZnO} / \mathrm{Al}$ [10]. In this device architecture, $\mathrm{Zn}^{2+}$ precursor is deposited on the $\mathrm{CdCl}_{2}$ treated $\mathrm{CdTe} \mathrm{NC}$ thin film and annealed at a moderate temperature of $300{ }^{\circ} \mathrm{C}$, which enables 
high quality junction formation and avoids large current leaks. However, efforts try to duplicate this device with an inverted structure of $\mathrm{ITO} / \mathrm{ZnO} / \mathrm{CdTe} / \mathrm{Au}$ failed due to the poor junction quality in the $\mathrm{ZnO}-\mathrm{CdTe}$ interface, which had been confirmed in our previous work [23]. It is noted that there are many merits for solar cells with inverted structure, such as a charge separating interface close to the illumination and usage of metal or metal oxide with high work function as a hole-collecting electrode, which endows device long lifetime. Solution processed CdTe NC based solar cells with inverted structure of ITO/CdSe/CdTe/Au were reported for the first time by Towsend et al. [19]. Although as high as 3.8\% PCE was obtained in the above devices, they suffered from low $V_{\text {oc }}(<0.5 \mathrm{~V})$ value, much lower than that (up to $0.8 \mathrm{~V}$ ) of CdTe/CdS devices prepared by close space sublimation (CSS) method [24]. With $\mathrm{Cr} / \mathrm{Au}$ as hole collecting electrode, the $V_{\text {oc }}$ of devices with the structure of ITO/CdSe $/ \mathrm{CdTe} / \mathrm{Cr} / \mathrm{Au}$ can be further increased to $0.62 \mathrm{~V}$ [20]. By using $\mathrm{ZnO}$ as the interlayer, devices with an architecture of ITO/ZnO/CdSe/CdTe/Au obtain a high $V_{\text {oc }}$ of up to $0.6 \mathrm{~V}$ in conjunction with a high PCE of $\sim 6 \%$ reported in our recent work $[25,26]$. Recently, Yang et al. $[27,28]$ developed an in situ route to construct CdTe-CdS NC bulk heterostructure solar cells by direct thermal treatment of mercaptoethylamine stabilized CdTe NC. In this device structure, the formation of $n$-CdS shells on CdTe NC eliminated the recombination of carrier and improved the device performance. Recently, [29] introduced $\mathrm{p}$ type spiro-OMeTAD as the hole transport layer between CdTe NC thin film and Au electrode, as high as $0.71 \mathrm{~V}$ of $V_{\text {oc }}$ was obtained, which was the highest $V_{\text {oc }}$ value ever reported for solution-processed CdTe NC based solar cells. Another way to improve the $V_{\text {oc }}$ of CdTe $\mathrm{NC}$ based solar cells is to engineer the bandgap structure of the photo-generated electron-accepting materials. As previously reported [12], the trap state density of CdTe was $10^{14} \mathrm{~cm}^{-3}$, high doped density of n-type materials was necessary to fully deplete the CdTe NC film in order to increase the carriers' separating and collecting efficiencies. It had been found that, by using $\mathrm{n}$ type doped $\mathrm{TiO}_{2}$ as the electron acceptor, the performance of $\mathrm{PbS}$ colloidal quantum dot $/ \mathrm{TiO}_{2}$ heterojunction solar cells can be tailored and improved substantially [30]. Bulk hetero-junction structure was built as porous structure formed during the decomposition of Ti-sol, which improved carrier collecting efficiency. Herein, we introduce solution-processed $\mathrm{CdTe} \mathrm{NC} / \mathrm{TiO}_{2}$ hetero-junction solar cells consisting of $\mathrm{ZnO}$ film, thermal decomposition Sb-doped $\mathrm{TiO}_{2}$ film, and solution processed CdTe NC thin film. The carrier separating/collecting efficiency of solar cells can be improved by introducing Sb-doped in $\mathrm{TiO}_{2}$ as the electron acceptor. It is found that $V_{\text {oc }}$ up to $0.7 \mathrm{~V}$ can be obtained with a Sb-doped $\mathrm{TiO}_{2}$ electrode and as high as $0.74 \mathrm{~V}$ is obtained in the case of $8 \% \mathrm{Sb}$-doped $\mathrm{TiO}_{2}$ devices, which is the highest $V_{\text {oc }}$ ever reported for solution-processed CdTe NC based solar cells.

\section{Results and Discussion}

In the case of inverted structure CdTe NC based solar cells, the absorbance or transmission of window layers has a great effect on the light passing through the CdTe NC active layer. Window layers with a high light transmission in short wavelengths will increase the response of spectrum in the device. Figure 1 shows the transmission spectra and the root mean square of the absorption against photon energy of Sb-doped $\mathrm{TiO}_{2}$. The measurement is taken by using FTO as the standard sample. From Figure 1a, it can be seen that the $\mathrm{FTO} / \mathrm{ZnO} / \mathrm{Sb}-\mathrm{TiO}_{2}$ thin films block the light with a wavelength shorter than $400 \mathrm{~nm}$ and show almost transparent behavior for wavelengths from 400 to $1000 \mathrm{~nm}$. A little decrease in the transmission is found when the Sb doping concentration increases to $8 \%$. As shown in Figure $1 \mathrm{~b}$, the bandgap of the $\mathrm{Sb}$-doped $\mathrm{TiO}_{2}$ layer utilized in this work is in the range of 3.1-3.3 eV, which is derived by taking a tangent of straight line of this curve at $A=0(A=(\alpha h v))$. There are almost no changes with different $\mathrm{Sb}$ doping ratios, which imply that $\mathrm{Sb}$ doping does not change the bandgap of $\mathrm{TiO}_{2}$ thin film, in accordance with the previous report [30]. 

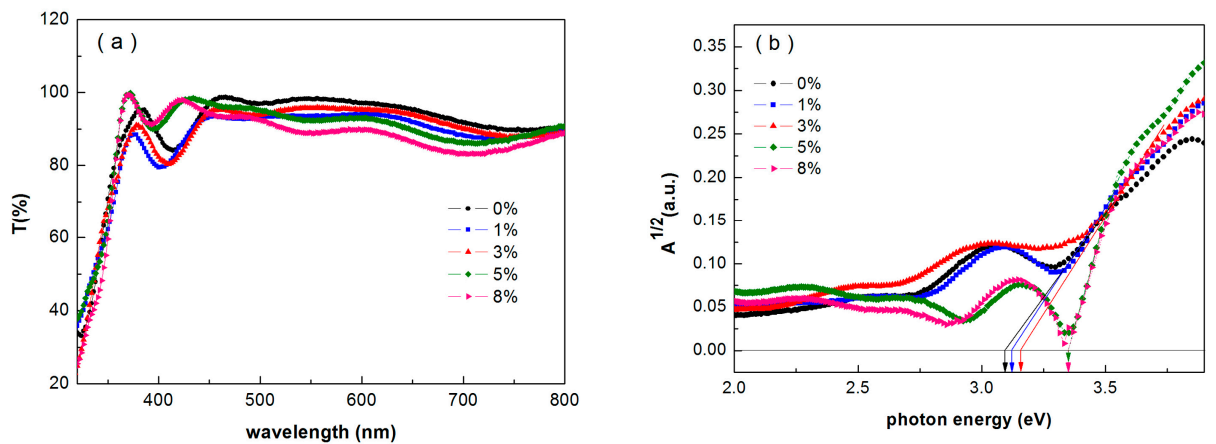

Figure 1. (a) Transmission spectra and (b) optical absorption curves of Sb-doped $\mathrm{TiO}_{2}$ thin film.

To build solar cells devices, we deposited five layers of CdTe NC thin film on $50 \mathrm{~nm}$ Sb-doped $\mathrm{TiO}_{2}$ and $40 \mathrm{~nm}$-thick $\mathrm{ZnO}$ thin film. Au is deposited on the CdTe layer to make ohmic contact. The cross-sectional SEM micrograph of this $\mathrm{CdTe}-\mathrm{TiO}_{2}$ device is also depicted in Figure 2a. The CdTe NC film is homogeneous with thickness $\sim 400 \mathrm{~nm}$. The band alignment of solar cells is presented in Figure 2b. Photoelectrons are generated in the CdTe NC active layer and separated in the $\mathrm{CdTe} / \mathrm{TiO}_{2}$ interface. The electrons are transported to $\mathrm{ZnO}$ and collected by the FTO, while photogenerated holes traveled to the Au electrode.
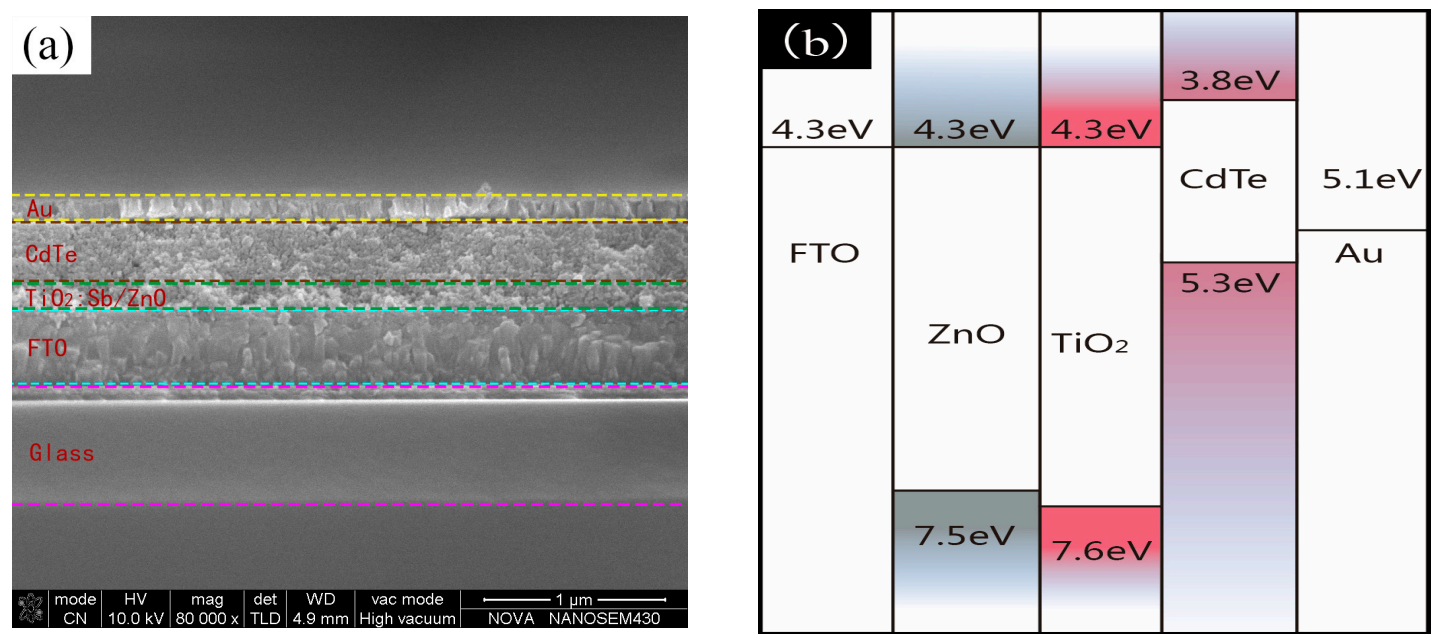

Figure 2. (a) Cross-sectional SEM images of the $\mathrm{FTO} / \mathrm{ZnO} / \mathrm{TiO}_{2} / \mathrm{CdTe} / \mathrm{Au}$ device architecture; (b) band alignment of $\mathrm{FTO}, \mathrm{ZnO}, \mathrm{TiO}_{2}, \mathrm{CdTe}$, and $\mathrm{Au}$.

The presented $\mathrm{ZnO}$ thin film can provide better electrical stability and the smooth and pin-hole free $\mathrm{TiO}_{2}$ film can be grown on it, which is confirmed in our previous work $[25,26]$. Furthermore, it can eliminate catastrophic shorts from the upper contact directly through CdTe layers to the FTO. For comparison, devices with structures of $\mathrm{FTO} / \mathrm{ZnO} / \mathrm{TiO}_{2} / \mathrm{CdTe} / \mathrm{Au}$ and $\mathrm{FTO} / \mathrm{TiO}_{2} / \mathrm{CdTe} / \mathrm{Au}$ are fabricated under the same conditions, that is, all devices consist of $50 \mathrm{~nm} \mathrm{TiO}{ }_{2}$ and $400 \mathrm{~nm} \mathrm{CdTe}$ active layers. The current density versus voltage $(J-V)$ characteristics of these devices under $1000 \mathrm{Wm}^{-2}$ (AM 1.5 G) are shown in Figure $3 \mathrm{a}$, while the dark $J-V$ curves are presented in Figure $3 \mathrm{~b}$. The $J_{\mathrm{sc}}$, $V_{\mathrm{oc}}, \mathrm{FF}$, and PCE values of the devices are summarized in Table 1. It is found that without $\mathrm{ZnO}$ film, the dark current is large. On the contrary, devices with a $\mathrm{ZnO}$ interlayer show good diode properties. The $J_{\mathrm{sc}}, V_{\mathrm{oc}}, \mathrm{FF}$ and PCE values of devices with the $\mathrm{ZnO}$ interlayer are $10.95 \mathrm{~mA} / \mathrm{cm}^{2}, 0.66 \mathrm{~V}, 30.35$ and $2.22 \%$ respectively, while these values for devices without the $\mathrm{ZnO}$ interlayer are $7.62 \mathrm{~mA} / \mathrm{cm}^{2}$, $0.63 \mathrm{~V}, 28.53$, and $1.37 \%$. We suppose that $\mathrm{TiO}_{2}$ deposited directly on the FTO substrate contains high 
interface defect density which can lead to high dark current and result in low device performance, confirming our previous work on ITO/ZnO/CdSe/CdTe/Au devices [26].
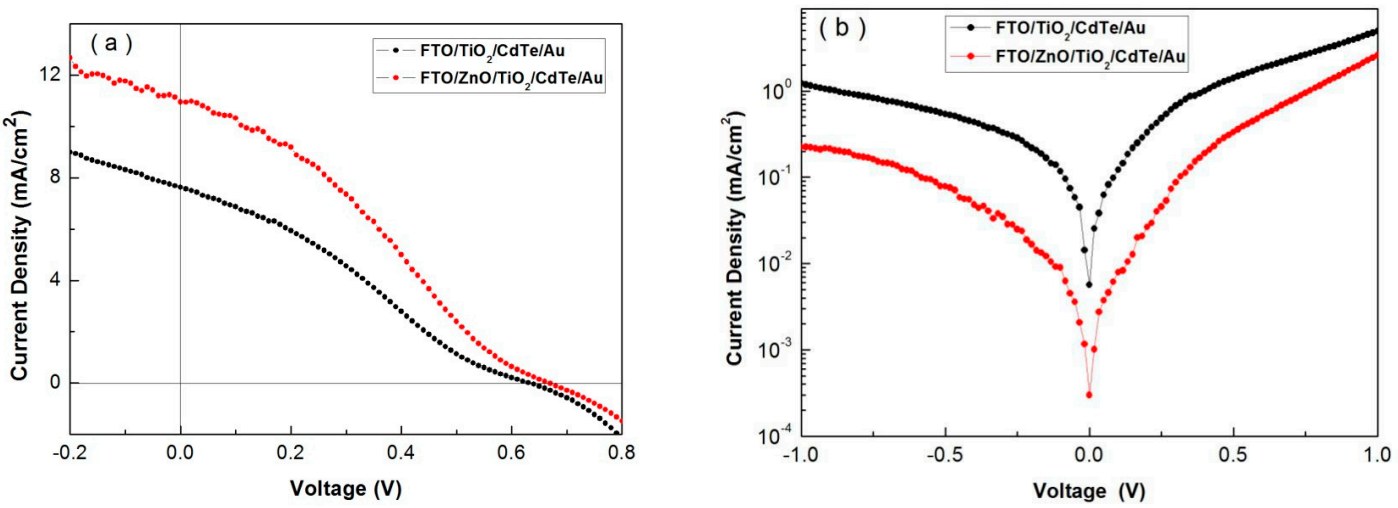

Figure 3. $J-V$ characteristics of $\mathrm{FTO} / \mathrm{ZnO} / \mathrm{TiO}_{2} / \mathrm{CdTe} / \mathrm{Au}$ and $\mathrm{FTO} / \mathrm{TiO}_{2} / \mathrm{CdTe} / \mathrm{Au}$ devices (a) under light and (b) dark.

Table 1. Summarized performances of $\mathrm{CdTe}-\mathrm{TiO}_{2}$ heterojunction solar cells w/o $\mathrm{ZnO}$ film

\begin{tabular}{lcccc}
\hline Device Structure & $\boldsymbol{V}_{\mathbf{~ o c}}(\mathbf{V})$ & $J_{\text {sc }}\left(\mathbf{m A} / \mathbf{c m}^{2}\right)$ & FF (\%) & PCE (\%) \\
\hline $\mathrm{FTO} / \mathrm{TiO}_{2} / \mathrm{CdTe} / \mathrm{Au}$ & 0.63 & 7.62 & 28.53 & 1.37 \\
$\mathrm{FTO} / \mathrm{ZnO} / \mathrm{TiO}_{2} / \mathrm{CdTe} / \mathrm{Au}$ & 0.66 & 10.95 & 30.35 & 2.22 \\
\hline
\end{tabular}

It was reported that the conduction band edge of $\mathrm{Sb}$-doped $\mathrm{TiO}_{2}$ is $-4.22 \mathrm{eV}$, while this value is $-3.81 \mathrm{eV}$ for undoped $\mathrm{TiO}_{2}$ [30]. The conduction band edge value of $\mathrm{Sb}$-doped $\mathrm{TiO}_{2}$ is lower than that of CdTe film $(-4.0 \mathrm{eV})$, which is promising for photo electron injecting to the conduction band of $\mathrm{TiO}_{2}$. To investigate the effect of different $\mathrm{Sb}$ doping contents on device performance, we fabricated $\mathrm{CdTe}$ $\mathrm{NC}$ based solar cells with different $\mathrm{Sb}$ contents of $1,3,5$, and $8 \%(w / w)$. Current density vs. voltage characteristics under AM 1.5 G illumination are shown in Figure 4a, and the device performances are listed in Table 2. The control devices (using undoped $\mathrm{TiO}_{2}$ ) shows a $V_{\text {oc }}$ of $0.66 \mathrm{~V}$ and PCE of $2.22 \%$, while all $\mathrm{Sb}$-doped $\mathrm{TiO}_{2}$ devices show higher $V_{\mathrm{oc}}$. Similar device performance is obtained in the case of low Sb-doped $\mathrm{TiO}_{2}$ device. The PCE of device increases linearly from $1 \%$ to $3 \% \mathrm{Sb}$-doped content, then decreases with the further increase of $\mathrm{Sb}$-doped content from 3\% to $8 \%$. The best device performance is obtained in the case of $3 \%(w / w)$ Sb-doped $\mathrm{TiO}_{2}$ electrodes. The $J_{\mathrm{sc}}, V_{\mathrm{oc}}, \mathrm{FF}$, and PCE values of device are $14.65 \mathrm{~mA} / \mathrm{cm}^{2}, 0.70 \mathrm{~V}, 34.44$, and $3.53 \%$ respectively. The PCE value of the $3 \%(w / w) \mathrm{Sb}$-doped device is $50 \%$ higher than that of the control device, mainly arising from the increase in $V_{\text {oc }}$ and $J_{\text {sc }}$. Compared to the controlled devices, $3 \%$ or $5 \% \mathrm{Sb}$-doped $\mathrm{TiO}_{2}$ devices show higher $V_{\text {oc }}$ coupled with higher PCE up to $3 \%$. The EQE spectra (Figure 4b) show that all Sb-doped $\mathrm{TiO}_{2}$ devices have higher EQE almost across the entire absorbing region compared to undoped $\mathrm{TiO}_{2}$ devices. This suggests that the transfer of photogenerated carriers in the Sb-doped devices is more effective than that in undoped devices. It is noted that the $V_{\text {oc }}$ is up to $0.69 \mathrm{~V}$ with different $\mathrm{Sb}$-doped devices and as high as $0.74 \mathrm{~V}$ is obtained in the case of $8 \% \mathrm{Sb}$-doped device. This is, to the best our knowledge, the highest $V_{\mathrm{oc}}$ reported for solution processed CdTe NC based solar cells. However, the PCE is decreased to $2.49 \%$ for $8 \% \mathrm{Sb}$-doped device. We suppose that, in the case of high $\mathrm{Sb}$-doped $\mathrm{TiO}_{2}$, excess $\mathrm{Sb}$ may act as recombination center for carrier, which will render the $J_{\mathrm{sc}}$ of device. It is also noted that "roll over" phenomena appear in the $J-V$ curves for different $\mathrm{CdTe}^{-\mathrm{TiO}_{2}}$ solar cells device, which may come from large series resistance of CdTe NC film. We believe that the low FF is mainly derived from low quality of CdTe NC thin film. The compactness, morphology, and grain size of CdTe NC is greatly affected by the substrate materials even all the same parameter for processing CdTe NC film. As CdTe and CdSe NCs have similar sizes and structures (zinc-blende or wurtzite), the lattice mismatch between 
CdTe and CdSe is very small. High quality CdTe NC film can be obtained with CdSe NC as interlayer and high solar cells performance is expected in this case, which has been confirmed in our previously reports $[25,26]$. However, when $\mathrm{CdTe} \mathrm{NCs}$ are deposited on $\mathrm{FTO} / \mathrm{ZnO} / \mathrm{TiO}_{2}$ by a layer-by-layer sintering process, low quality CdTe NC film with pinholes or other defects will be obtained as the lattice mismatch between $\mathrm{CdTe}$ and $\mathrm{TiO}_{2}$. The contact between $\mathrm{CdTe}$ and $\mathrm{Au}$ is non ohmic due to the large resistance existed in CdTe NC thin film, then $J-V$ curves with cross over behavior are likely observed in this case. The principal path to $\mathrm{CdTe} \mathrm{NC}^{-\mathrm{TiO}_{2}}$ solar cells' further improvement lies in continued reductions in electronic trap state densities in the junction, improving the quality of $\mathrm{CdTe}$ NC film and optimizing the contact for CdTe NC film.
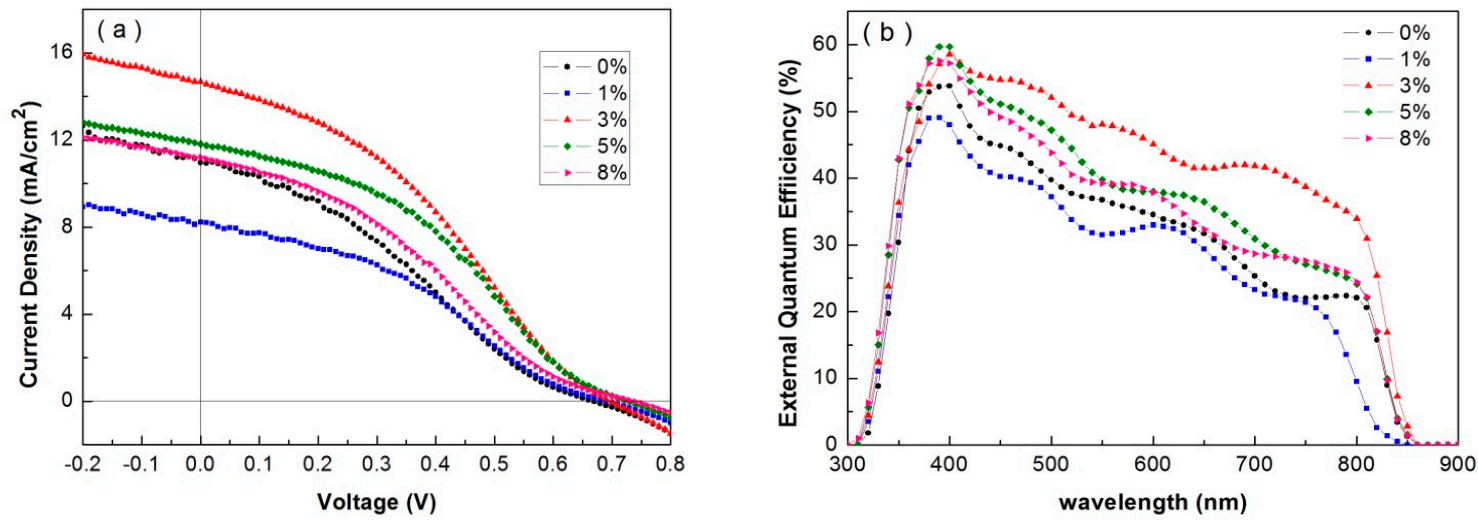

Figure 4. $J-V$ characteristics of $\mathrm{FTO} / \mathrm{ZnO} / \mathrm{Sb}: \mathrm{TiO}_{2} / \mathrm{CdTe} / \mathrm{Au}$ with dopant concentration (a) under light and (b) EQE properties of devices.

Table 2. Summarized performances of $\mathrm{CdTe}-\mathrm{TiO}_{2}$ heterojunction solar cells with dopant concentration.

\begin{tabular}{ccccc}
\hline Sb Content $(w / w)$ & $V_{\text {oc }}(\mathbf{V})$ & $J_{\text {sc }}\left(\mathbf{m A} / \mathbf{c m}^{2}\right)$ & FF (\%) & PCE (\%) \\
\hline $0 \%$ & 0.66 & 10.95 & 30.35 & 2.22 \\
$1 \%$ & 0.69 & 8.24 & 34.76 & 1.97 \\
$3 \%$ & 0.70 & 14.65 & 34.44 & 3.53 \\
$5 \%$ & 0.72 & 11.83 & 36.58 & 3.13 \\
$8 \%$ & 0.74 & 11.16 & 30.13 & 2.49 \\
\hline
\end{tabular}

To investigate the mobility of $\mathrm{TiO}_{2}$ with dopant concentrations, we deposit $\mathrm{TiO}_{2}$ on the FTO substrate and use $\mathrm{Al}$ as the contact electrodes. As shown in Figure 5, the electron mobility is calculated by the formula of $J=\frac{9}{8} \frac{\varepsilon \mu_{n} V^{2}}{L^{3}}$ [13], where $\varepsilon$ is the relative dielectric constant, $V_{\mathrm{bi}}$ is the potential difference between FTO and $\mathrm{TiO}_{2}\left(V_{\mathrm{bi}}=0.1 \mathrm{~V}\right.$ in this case), $V_{\mathrm{s}}$ is the applied voltage, $L$ is the thickness of the $\mathrm{TiO}_{2}$ active layer ( $\sim 50 \mathrm{~nm}$ in this case). In the case of undoped $\mathrm{TiO}_{2}$, it shows a relative low electron mobility of $0.19 \times 10^{-5} \mathrm{~cm}^{2} \mathrm{~V}^{-1} \mathrm{~s}^{-1}$, which implies that large surface states exist in the film. The electron mobility increases with the Sb-doped content increase linearly (as $8 \%$ and $5 \%$ Sb-doped $\mathrm{TiO}_{2}$ have similar mobility the $J-V$ curve for $8 \% \mathrm{Sb}$-doped $\mathrm{TiO}_{2}$ is not presented here). The mobility of $\mathrm{TiO}_{2}$ film has a great effect on the performance of NC based solar cells. Film with a high mobility may markedly reduce the recombination of electrons and holes during the transfer of carriers and a high $J_{\mathrm{sc}}$ is expected to be obtained in this case, which is consistent with our $J-V$ curve measurement of CdTe $\mathrm{NC}$ based solar cells with different $\mathrm{Sb}$-doped $\mathrm{TiO}_{2}$ electrodes (see Table 2). 

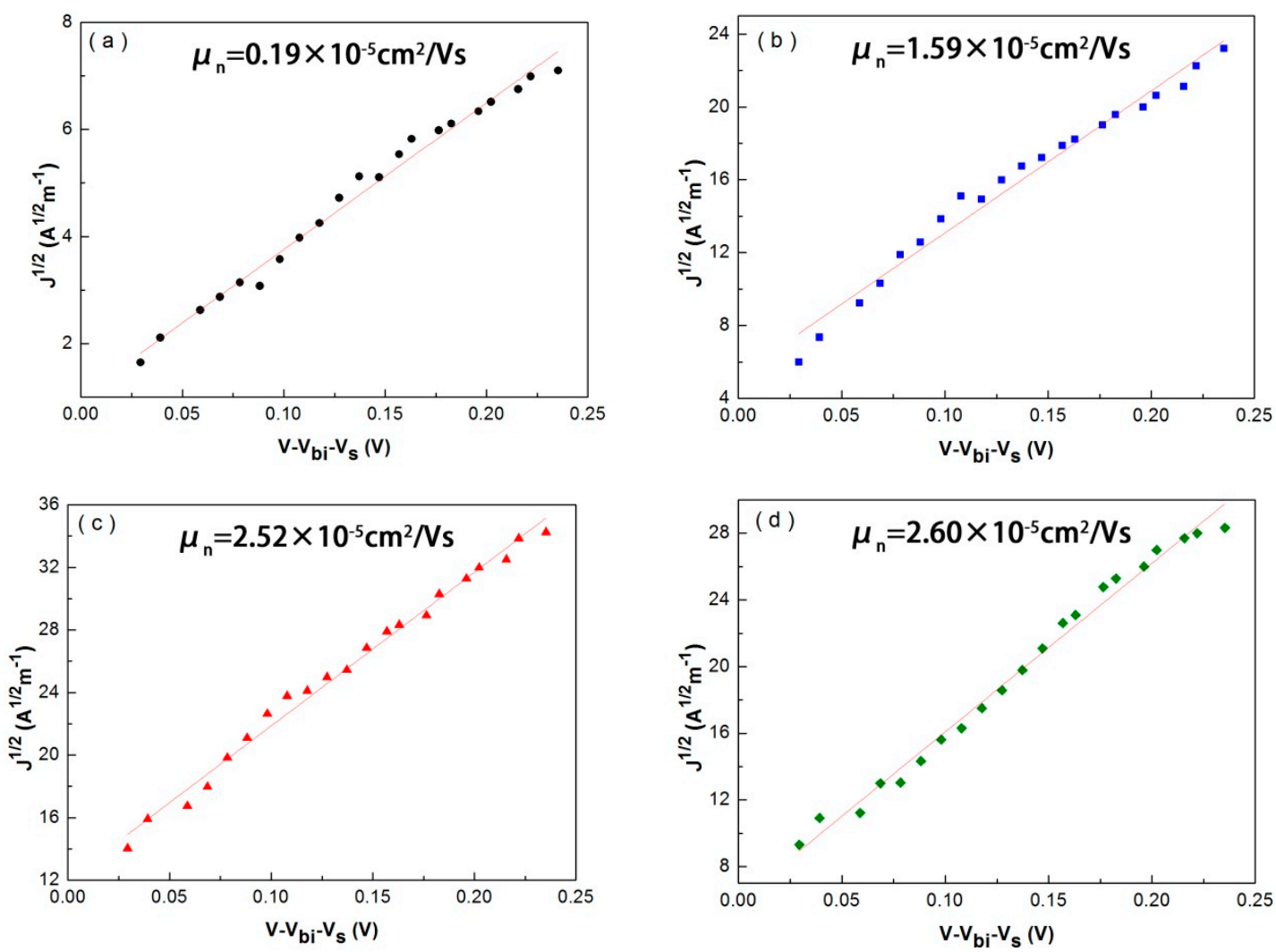

Figure 5. SCLC measurements of $\mathrm{TiO}_{2}$ thin films with dopant concentration a $0 \% \mathrm{Sb}$-doped (a); $1 \%$ Sb-doped (b); 3\% Sb-doped (c); and 5\% Sb-doped (d).

\section{Materials and Methods}

The preparation of $\mathrm{TiO}_{2}$-sol with different $\mathrm{Sb}$ contents was carried out under ambient conditions. In a typical $3 \%(w / w)$ Sb-doped $\mathrm{TiO}_{2}$ precursor, titanium $n$-butoxide $(4.25 \mathrm{~mL})$ was mixed with ethanolamine $(3.75 \mathrm{~mL})$ and ethyl alcohol $(25 \mathrm{~mL})$ in a beaker under continuous stirred for $2 \mathrm{~h} .5 \mathrm{~mL}$ acetic acid, $5 \mathrm{~mL}$ deionized water, and $8.33 \mathrm{uL}$ antimony(III) ethoxide (with $\mathrm{Sb}$ to $\mathrm{Ti}=1: 20$ ) were added into the mixture and placed in a fume hood to allow condensation reactions. After three days, the volume of Ti-sols was about $15 \mathrm{~mL}$. The Ti-sols were then transferred into a clean vial for $\mathrm{TiO}_{2}$ film fabrication. By varying the ratio of $\mathrm{Sb}^{2+}$ to titanium $n$-butoxide in the mixture, we obtained Ti-sol with dopant concentration. The fabrication of $\mathrm{ZnO}$ precursor and CdTe NC could be found in our previous reports [25,31].

The CdTe NC based solar cells with $\mathrm{FTO} / \mathrm{ZnO} / \mathrm{TiO}_{2}: \mathrm{Sb} / \mathrm{CdTe} / \mathrm{Au}$ structures were fabricated by a layer-by-layer solution process. Firstly, the $\mathrm{ZnO}$ precursor was spin-coated on FTO at a speed of $3000 \mathrm{rpm}$ for $20 \mathrm{~s}$. Then the sample was annealed at $200{ }^{\circ} \mathrm{C}$ for $10 \mathrm{~min}$ and then $400{ }^{\circ} \mathrm{C}$ for $10 \mathrm{~min}$. Several drops of the Ti-sols were deposited on the FTO/ZnO substrates by spin coating at 2500rpm for $15 \mathrm{~s}$. The sample was immediately transferred to a hot plate at $500{ }^{\circ} \mathrm{C}$ for $60 \mathrm{~min}$. The deposition of $\mathrm{CdTe}$ film can be found in our previous report [25]. The final products were annealed at $400{ }^{\circ} \mathrm{C}$ for $15 \mathrm{~min}$. Au with $80 \mathrm{~nm}$ thickness was deposited on the CdTe film via thermal evaporation to make back contact.

\section{Conclusions}

In conclusion, we demonstrated that inverted CdTe NC based solar cells fabricated with different $\mathrm{Sb}$-doped $\mathrm{TiO}_{2}$ electrodes have many benefits such as simple structure, easy control, less interface defects, high electron mobility, and ideal band offsets for carrier separation, which results in good 
device performance. In the case of $3 \% \mathrm{Sb}$-doped $\mathrm{TiO}_{2}$ device, we obtain a high $V_{\text {oc }}$ up to $0.7 \mathrm{~V}$ with PCE of $3.53 \%$. $V_{\text {oc }}$ as high as $0.74 \mathrm{~V}$ is obtained in the case of an $8 \% \mathrm{Sb}$-doped device. The Sb doping ratio is found to have great effect on the device performance. Our results imply that if a CdTe layer, a Sb-doped $\mathrm{TiO}_{2}$ layer, and their junction undergo more optimized processing (such as increasing annealing temperature or annealing time), the device performance can be further increased. This exploration gives more insight into solution processed CdTe NC based solar cells with Sb-doped $\mathrm{TiO}_{2}$ electrodes.

Acknowledgments: We are thankful the financial support of the National Natural Science Foundation of China (Nos. 91333206, 61274062 and 11204106), National Science Foundation for Distinguished Young Scholars of China (Grant No. 51225301), Guangdong Province Natural Science Fund (No. 2014A030313257), National Undergraduate Innovative and Entrepreneurial Training Program (No. 201610561070) and the Fundamental Research Funds for the Central Universities.

Author Contributions: Donghuan Qin and Miaozi Li conceived and designed the experiments; Miaozi Li, Xinyan Liu, Shiya Wen, Songwei Liu and Jingxuan Heng performed the experiments; Wei Xu and Miaozi Li analyzed the data; Lintao Hou, Wenbo Huang, Hongbin Wu and Miaozi Li contributed reagents/materials/analysis tools; Donghuan Qin and Miaozi Li wrote the paper. Authorship must be limited to those who have contributed substantially to the work reported.

Conflicts of Interest: The authors are declared no conflict of interest.

\section{References}

1. Kagan, C.R.; Lifshitz, E.; Sargent, E.H.; Talapin, D.V. Building devices from colloidal quantum dots. Science 2016, 353, aac5523. [CrossRef] [PubMed]

2. Lan, X.Z.; Voznyy, O.; Kiani, A.; de Arquer, F.P.G.; Abbas, A.S.; Kim, G.H.; Liu, M.X.; Yang, Z.Y.; Walters, G.; Xu, J.X.; et al. Passivation using molecular halides increases quantum dot solar cell performance. Adv. Mater. 2016, 28, 299-304. [CrossRef] [PubMed]

3. Lan, X.Z.; Voznyy, O.; de Arquer, F.P.G.; Liu, M.; Xu, J.X.; Proppe, A.H.; Walters, G.; Fan, F.J.; Tan, H.R.; Liu, M.; et al. $10.6 \%$ Certified colloidal quantum dot solar cells via solvent-Polarity-Engineered halide passivation. Nano Lett. 2016, 16, 4630-4634. [CrossRef] [PubMed]

4. Xue, H.; Wu, R.; Xie, Y.; Tan, Q.; Qin, D.; Wu, H.; Huang, W. Recent progress on Solution-Processed CdTe nanocrystals solar cells. Appl. Sci. 2016, 6, 197. [CrossRef]

5. Halim, M.A. Harnessing sun's energy with quantum dots based next generation solar cell. Nanomaterials 2013, 3, 22-47. [CrossRef] [PubMed]

6. Wei, J.; Xiong, Q.Y.; Mahpeykar, S.M.; Wang, X.H. Numerical study of complementary nanostructures for light trapping in colloidal quantum dot solar cells. Nanomaterials 2016, 6, 55. [CrossRef] [PubMed]

7. Yuan, C.Z.; Li, L.; Huang, J.; Ning, Z.J.; Sun, L.C.; Agren, H. Improving the photocurrent in Quantum-Dot-Sensitized solar cells by employing alloy PbxCd1-xS quantum dots as photosensitizers. Nanomaterials 2016, 6, 97. [CrossRef] [PubMed]

8. Chen, G.; Ning, Z.; Agren, H. Nanostructured Solar Cells. Nanomaterials 2016, 6, 145. [CrossRef] [PubMed]

9. Kang, Y.J.; Yang, P.D.; Markovic, N.M.; Stamenkovic, V.R. Shaping electrocatalysis through tailored nanomaterials. Nano Today 2016, 11, 587-600. [CrossRef]

10. Panthani, M.G.; Kurley, J.M.; Crisp, R.W.; Dietz, T.C.; Ezzyat, T.; Luthur, J.M.; Talapin, D.V. High efficiency solution processed sintered CdTe nanocrystal solar cells: The role of interfaces. Nano Lett. 2014, 14, 670-675. [CrossRef] [PubMed]

11. Crisp, R.W.; Panthani, M.G.; Rance, W.L.; Duenow, J.N.; Parilla, P.A.; Callahan, R.; Dabney, M.S.; Berry, J.J.; Talapin, D.V.; Luther, J.M. Nanocrystal grain growth and device architectures for high-efficiency CdTe Ink-Based photovoltaics. ACS. Nano 2014, 8, 9063. [CrossRef] [PubMed]

12. Jasieniak, J.; MacDonald, B.I.; Wakins, S.E.; Mulvaney, P. Solution-processed sintered nanocrystal solar cells via Layer-by-Layer assembly. Nano Lett. 2011, 11, 2856-2864. [CrossRef] [PubMed]

13. Yang, Y.; Zhao, B.; Gao, Y.; Liu, H.; Tian, Y.; Qin, D.; Wu, H.; Hou, L.; Huang, W. Novel hybrid ligands for passivating $\mathrm{PbS}$ colloidal quantum dots to enhance the performance of solar cells. Nano-Micro Lett. 2015, 7, 325-331. [CrossRef] 
14. Chen, Z.; Zhang, H.; Du, X.; Cheng, X.; Chen, X.; Jiang, Y.; Yang, B. From planar-heterojunction to $n-i$ structure: An efficient strategy to improve short-circuit current and power conversion efficiency of aqueous-solution-processed hybrid solar cells. Energy Environ. Sci. 2013, 6, 1597-1603. [CrossRef]

15. Du, X.; Chen, Z.; Li, Z.; Hao, H.; Zeng, Q.; Dong, C.; Yang, B. Dip-Coated Gold Nanoparticle Electrodes for Aqueous-Solution-Processed Large-Area Solar Cells. Adv. Energy Mater. 2014, 4, 1400135. [CrossRef]

16. Chen, Z.; Zhang, H.; Li, Z.; Hao, H.; Zeng, Q.; Wang, Y.; Du, X.; Wang, L.; Yang, B. In situ construction of nanocrystal CdTe-CdS bulk heterojunctions for inorganic nanocrystal solar cells. Adv. Energy Mater. 2014, 4, 1400235. [CrossRef]

17. Anderson, I.E.; Breeze, A.J.; Olson, J.D.; Yang, L.; Sahoo, Y.; Cater, S.A. ALL-inorganic spin-cast nanoparticle solar cells with nonselective electrodes. Appl. Phys. Lett. 2009, 94, 063101. [CrossRef]

18. Zhu, J.; Yang, Y.; Gao, Y.; Qin, D.; Wu, H.; Hou, L.; Huang, W. Enhancement of open-circuit voltage and the fill factor in CdTe nanocrystal solar cells by using interface materials. Nanotechnology 2014, 25, 365203. [CrossRef] [PubMed]

19. Townsend, T.K.; Foos, E.E. Fully solution processed all inorganic nanocrystal solar cells. Phys. Chem. Chem. Phys. 2014, 16, 16458-16464. [CrossRef] [PubMed]

20. Yoon, W.; Townsend, T.K.; Lumb, M.P.; Tischler, J.G.; Foos, E.E. Sintered CdTe nanocrystal thin films: determination of optical constants and applications in novel inverted heterojunction solar cells. IEEE Trans. Nanotechnol. 2014, 13, 551-556. [CrossRef]

21. MacDonald, B.I.; Martucci, A.; Rubanov, S.; Wakins, S.E.; Mulvaney, P.; Jasieniak, J.J. Layer-by-Layer Assembly of Sintered CdSe $\mathrm{Te}_{1-x}$ Nanocrystal Solar Cells. ACS Nano. 2012, 6, 5995-6004. [CrossRef] [PubMed]

22. Shi, S.; Liu, H.; Gao, Y.; Qin, D.; Chen, J. Controlled synthesis of CdTe nanocrystals for high performanced Schottky thin film solar cells. J. Mater. Chem. 2012, 22, 19207-19212.

23. Tian, Y.; Zhang, Y.; Lin, Y.; Gao, K.; Zhang, Y.; Liu, K.; Yang, Q.; Zhou, X.; Qin, D.; Wu, H.; et al. Solution-processed efficient CdTe nanocrystal/CBD-CdS hetero-junction solar cells with ZnO interlayer. J. Nanopart. Res. 2013, 15, 2053. [CrossRef]

24. Green, M.A.; Emery, K.; Hishikawa, Y.; Warta, W.; Dunlop, E.D.; Levi, D.H.; Ho-Baillie, A.W.Y. Solar cell efficiency tables. Prog. Photovolt. Res. Appl. 2017, 25, 3-13. [CrossRef]

25. Xie, Y.; Tan, Q.X.; Zhang, Z.T.; Lu, K.K.; Li, M.Z.; Xu, W.; Qin, D.H.; Zhang, Y.D.; Hou, L.T.; Wu, H.B. Improving performance in $\mathrm{CdTe} / \mathrm{CdSe}$ nanocrystals solar cells by using bulk nano-heterojunctions. J. Mater. Chem. C 2016, 4, 6419-6676. [CrossRef]

26. Liu, H.; Tian, Y.Y.; Zhang, Y.J.; Gao, K.; Qin, D.H. Solution processed CdTe/CdSe nanocrystal solar cells with more than 5.5\% efficiency by using an inverted device structure. J. Mater. Chem. C 2015, 3, 4227-4234. [CrossRef]

27. Zhang, H.; Kurley, J.M.; Russell, J.C.; Jang, J.; Talapin, D.V. Solution-processed, ultrathin solar cells from $\mathrm{CdCl}_{3}{ }^{-}$-Capped CdTe nanocrystals: The multiple roles of $\mathrm{CdCl}_{3}{ }^{-}$ligands. J. Am. Chem. Soc. 2016, 138, 7464-7467. [CrossRef] [PubMed]

28. Chen, Z.; Zeng, Q.; Liu, F.; Jin, G.; Du, X.; Du, J.; Zhang, H.; Yang, B. Efficient inorganic solar cells from aqueous nanocrystals: The impact of composition on carrier dynamics. RSC Adv. 2015, 5, 74263-74269. [CrossRef]

29. Du, X.; Chen, Z.; Liu, F.; Zeng, Q.; Jin, G.; Li, F.; Yao, D.; Yang, B. Improvement in open-circuit voltage of thin film solar cells from aqueous nanocrystals by interface engineering. ACS. Appl. Mater. Interfaces 2016, 8 , 900-907. [CrossRef] [PubMed]

30. Liu, H.; Tang, J.; Kramer, I.J.; Debnath, R.; Koleilat, G.I.; Wang, X.; Fisher, A.; Li, R.; Brzozowski, L.; Levina, L.; et al. Electron acceptor materials engineering in colloidal quantum dot solar cells. Adv. Mater. 2011, 23, 3832-3837. [CrossRef] [PubMed]

31. Yang, T.; Cai, W.; Qin, D.; Wang, E.; Lan, L.; Gong, X.; Peng, J.; Cao, J. Solution-Processed Zinc Oxide thin film as a buffer layer for polymer solar cells with an inverted device structure. J. Phys. Chem. C 2010, 114, 6849-6854. [CrossRef] 